\title{
ANALISIS POLA PEMBIAYAAN PRODUK TURUNAN PALA SEBAGAI KOMODITI PANGAN UNGGULANDI PROVINSI SULAWESI UTARA
}

\author{
Caroline B.D. Pakasi \\ Ellen Tangkere
}

\begin{abstract}
Analysis of the financing pattern of nutmeg derivative products as featured food commodities in North Sulawesi province is important because Pala as a unique commodity that has economic value of an important food in the area. Nutmeg plant parts that have economic value is part of the fruit is composed of 83.3 per cent of the fruit flesh; 3.22 percent mace; Shell beans 3.94 percent, and 9.54 percent of the meat seeds. The specific objective of this study is to identify the type and Value Added Food Products Derived Pala as seed and analyze the pattern of financing products derived nutmeg as featured food commodities in North Sulawesi Province. This research was conducted in the central areas of the North Sulawesi province Pala in Sitaro Islands Regency (Sitaro). Identification will be conducted on several types of meat derived products will be analyzed nutmeg and nutmeg as a development financing patterns featured food commodities in North Sulawesi Province. The results showed that there are three types of food products derived nutmeg seed as the Dodo Nutmeg, Nutmeg Butter and Syrup Pala. Household businesses are identified financed by Four Types of Financing Pattern. They are the Financing Pattern of Government, Financing Pattern of Banking through Bank Indonesia, Pattern Loan Financing fellow entrepreneurs who have capital and Financing Pattern Alone. Featured Product Development Food must be improved by facilitating the entrepreneurs to get venture capital to increase the capacity of the Financing Patterns provided, or by credit facilities from banks.
\end{abstract}

Keywords: Food Commodity, Derivative Products Meat Fruit Pala, Pattern Financing

\begin{abstract}
Analisis pola pembiayaan produk turunan pala sebagai komoditi pangan unggulandi Provinsi Sulawesi Utara penting dilakukan karena Pala sebagai komoditi unggulan yang unik memiliki nilai ekonomi pangan yang penting di daerah. Bagian tanaman pala yang mempunyai nilai ekonomis adalah bagian buah yang terdiri dari 83,3 persen daging buah; 3,22 persen fuli; 3,94 persen tempurung biji, dan 9,54 persen daging biji.Tujuan khususpenelitian ini adalah untuk mengidentifikasi Jenis danNilai Tambah Produk Turunan PalasebagaiPanganUnggulan dan menganalisis pola pembiayaan produk turunan pala sebagai komoditi pangan unggulan di Provinsi Sulawesi Utara. Penelitian ini dilakukan di daerah sentra Pala Provinsi Sulawesi Utara yakni di Kabupaten Kepulauan Siau Tagulandang Biaro (Sitaro). Identifikasi akan dilakukan terhadap beberapa jenis produk turunan daging buah pala dan akan dianalisis pola pembiayaan pengembangan pala sebagai komoditi pangan unggulan di Provinsi Sulawesi Utara.Hasil penelitian menunjukkan bahwa terdapat tiga jenis produk turunan pala sebagai pangan unggulan yakni Dodol Pala, Selai Pala dan Sirup Pala.Usaha Rumahtangga tersebut teridentifikasi dibiayai dengan Empat Jenis Pola Pembiayaan. Yakni,Pola Pembiayaan dari Pemerintah, Pola Pembiayaan dari Perbankan melalui Bank Indonesia, Pola Pembiayaan Pinjaman sesama Pengusaha yang memiliki modal dan Pola Pembiayaan Sendiri.Pengembangan Produk Unggulan Pangan harus terus ditingkatkan dengan memfasilitasi pengusaha mendapatkan modal untuk meningkatkan kapasitas usaha dengan Pola Pembiayaan yang tersedia, ataupun dengan fasilitas kredit dari Perbankan.
\end{abstract}

Kata kunci: Pangan Unggulan, Produk Turunan Daging Buah Pala, Pola Pembiayaan 


\section{PENDAHULUAN}

Ketahanan pangan dengan memanfaatkan beragam sumber bahan baku pangan merupakan program prioritas menuju kemandirian pangan. Sumberdaya pangan di daerah secara lokal harus dioptimalkan pemanfaatannya untuk memenuhi pangan masyarakat serta program diversfikasi pangan unggulan daerah.

Provinsi Sulawesi Utara merupakan daerah penghasil tanaman perkebunan seperti tanaman Kelapa, Cengkeh dan Pala. Tanaman Pala merupakan tanaman yang menghasilkan buah yang terdiri dari daging dan biji yang dilapisi dengan fulli yang memiliki nilai jual tinggi.Tanaman Pala tersebar di daerah kepulauan yakni di Kabupaten Kepulauan Siau Tagulandang Biaro (SITARO), Kabupaten Kepulauan Sangihe dan Kabupaten Kepulauan Talaud.Selain buah Pala dari daerah kepulauan, terkenal juga buah Pala dari daratan yakni dari Kabupaten Minahasa Utara.Namun, buah Pala yang unggul dan potensial berasal dari Kabupaten Kepulauan Siau Tagulandang Biaro, yang dikenal dengan sebutan Pala Siau atau Siau Nutmeg.Keunggulan dan keunikan Pala Siau telah diperkuat dengan ditetapkannya Pengembangan Indikasi Geografis yang merupakan suatu Nilai Tambah Komoditas.Indikasi Geografis terhadap Pala Siau dalam perdagangan internasional, disamping harga, sebagian besar persaingan terletak pada ciri khas, keunggulan dan konsistensi mutu produk. Produk yang berciri khas dan bermutu tinggi secara konsisten akan banyak dicari dan akan mendapatkan tempat khusus dalam perdagangan internasional.

Sebagai tanaman asli Indonesia, Tanaman Pala (Myristica fragrans houtt) yang berasal dari pulau Banda dan telah berkembang di Kabupaten Kepulauan Siau Tagulandang Biaro, memiliki ciri khas dari suatu produk yang terjadi karena faktor geografis, keadaan tanah dan iklim yang khas dari daerah penghasil atau faktor budaya masyarakat setempat.Dengan indikasi geografis pada Pala Siau, menunjukkan bahwa Pala Siau telah memilki ciri kualitas tertentu karena faktor geografis termasuk faktor alam, faktor manusia atau kombinasi kedua faktor tersebut.

Secara komersial biji Pala dan fulli merupakan bagian terpenting dari buah Pala dan dapat dibuat menjadi berbagai produk antara lain minyak atsiri dan oleoresin. Produk lain yang mungkin dibuat dari biji Pala adalah mentega Pala yaitu trimiristin yang dapat digunakan untuk minyak makan dan industri kosmetik
(Somaatmaja, 1984). Buah Pala yang lebih banyak dikenal sebagai komoditi penghasil bumbu yang bernilai tinggi, ternyata memiliki bagian Daging Buah Pala yang berpotensi sebagai Bahan Pangan untuk menunjang ketahanan pangan daerah. Daging Buah Pala dapat diolah menjadi beragam jenis makanan dan minuman untuk ketahanan pangan dan memiliki fungsi kesehatan bagi tubuh.

Buah Pala merupakan buah eksotik sejak zaman penjajahan merupakan buah bernilai tinggi karena biji dan fullinya, sedangkan dagingnya sejak zaman dahulu juga sudah menjadi sumber pangan bagi pekerja perkebunan pala, karena daging pala ditinggalkan dikebun setelah biji dan fulli pala dipisahkan dari daging. Daging pala menjadi bahan makanan bagi pekerja perkebunan pala dan hingga saat ini berpotensi menjadi pangan unggulan daerah.

\section{Tujuan Penelitian}

1. Mengidentifikasi Produk Turunan Pala Unggulan di daerah sentra;

2. Menganalisis Pola Pembiayaan Dari Produk Turunan Pala sebagai Pangan Unggulan di Provinsi Sulawesi Utara.

\section{Sasaran Penelitian}

1. Pengusaha Industri Mikro dan Kecil Pengolahan Pangan Makanan dan Minuman Berbahan Baku Daging Buah Pala

2. Pemerintah Daerah Terkait Pengembangan Industri Mikro dan Kecil Pengolahan Pangan Berbahan Baku Buah Daging Pala.

3. Sumber Pembiayaan untuk mengidentifkasi Pola Pembiayaan

\section{Bentuk Luaran yang Dijanjikan}

1. Teridentifikasi potensi pangan dari daging buah Pala

2. Tersedianya informasi pola pembiayaan produk turunan daging buah Pala sebagai pangan unggulan di Provinsi Sulawesi Utara

3. Terpublikasi hasil penelitian dalam Jurnal Ilmiah, Menjadi bahan kajian akademik dalam penyusunan kebijakan (pedoman, regulasi) ketersediaan pangan unggulan daerah berbahan baku komoditi lokal

4. Menjadi Bahan Kajian, dalam upaya pengembangan dan penerapan Ipteks-Sosbud untuk ketersediaan pangan unggulan berbahan baku Daging Buah Pala di Kabupaten Kepulauan Siau Tagulandang Biaro. 


\section{METODOLOGI PENELITIAN}

\section{Tempat dan Waktu Penelitian}

Penelitian ini dilaksanakan di sentra komoditi Pala terbesar di Provinsi Sulawesi Utara yakni di Kabupaten KepulauanSiau Tagulandang Biaro.Waktu penelitian selama 6 bulan. Kegiatan penelitian diawali dengan Identifikasi jenis pangan unggulan berbahan baku daging buah pala di Kabupaten Kepulauan Sitaro Provinsi Sulawesi Utara

\section{Data Penelitian}

Penelitian ini menggunakan Data Primer dan Data Sekunder. Data Primer di peroleh dari 45 pengolah produk pangan berbahan baku Pala di Daerah Sentra Kabupaten Kepulauan Siau Tagulandang Biaro (SITARO). Data sekunder diperoleh dari instansi yang terkait seperti Dinas Perkebunan, Badan Ketahanan Pangan, Dinas Perindustrian dan Perdagangan, Dinas Koperasi dan UMKM serta stakeholder lainnya yang terkait.

\section{Konsepsi Pengukuran Variabel}

1. Luas Perkebunan Pala (Ha)

2. Jumlah Pohon Pala (Pohon)

3. Produksi Pala (kg/thn)

4. Jenis Produk turunan

5. Biaya Bahan Baku (Rp/kg)

6. Biaya Bahan Penolong (Rp/kg)

7. Harga produk turunan pala $(\mathrm{Rp} / \mathrm{kg})$

8. Ketersediaaan Bahan Baku

9. Jaminan Pasar

10. Ketersediaan Tenaga Kerja

11. Pengetahuan Pengolahan Produk

12. Sumber Modal

\section{a. Studi Awal}

\section{Ruang Lingkup Pekerjaan}

Pengumpulan data sekunder berupa data-data terkait produksi pala dan turunannya, selanjutnya dikumpukan juga data kapasitas produksi pala termasuk jumlah daging pala yang tidak termanfaatkan. Data sekunder diperoleh melalui studi dokumen atau literatur yang terkait.

\section{b. Persiapan Administrasi dan Survey}

Mengidentifikasi berdasarkan data primer dan sekunder potensi pala sebagai kekuatan ekonomi lokal serta produk turunannya yang berpotensi sebagai pangan unggulan di Provinsi Sulawesi Utara, khususnya di sentra produksi Pala Siau di Kabupaten Kepulauan Sitaro.

\section{c. Analisa Hasil Identifikasi}

1. Menganalisis aspek Produksi Pala (bahan baku, Tenaga Kerja, Proses Pengolahan)

2. Menganalisis aspek Pemasaran (Jaminan Pasar)

3. Menganalisis aspek Keuangan (Modal)

\section{Metode Penelitian}

Penelitian ini menggunakan metode penelitian kualitatif dan kuantitatif dengan analisis. Hasil analisis akan dideskripsikan dan dibahas secara detail berdasarkan kondisi eksisting, analisis keuangan dilakukan untuk pola pembiayaan.

\section{Prosedur penelitian}

Tahap pertama melakukan identifikasi jenis produk turunan pala yang berpotensi sebagai pangan unggulan, selanjutnya melakukan anaalisis terhadap potensi produksi, analisis pemasaran dan analisis keuangan, sehingga produk pangan unggulan berbahan baku daging pala akan bernilai tambah, apalagi bahan baku pala Siau telah teridentifikasi secara geografis yang memberikan keunggulan tersendiri terhadap produk pala Siau yang dihasilkan.

\section{Analisa Data.}

Metode yang digunakan dalam mengidentifikasi kondisi eksisting produk turunan pala dan analisis ekonomi pangan unggulan berbahan baku daging buah pala yang akan dianalisis menggunakan metode kualitatifkuantitatif. Menganalisis Prouk Turunan Pala Unggulan, dianalsis secara deskriptif berdasarkan indikator produk unggulan. Analisis Finansial mengikuti pola baku dalam analisis evaluasi proyek kegiatan pengolahan produksi pangan.

\section{HASIL DAN PEMBAHASAN}

\section{Eksisting Perkebunan Pala Provinsi Sulawesi Utara}

Provinsi Sulawesi Utara adalah salah satu daerah penghasil Pala dengan luas areal kurang lebih $19 \%$ dari luas areal nasional dan tersebar hampir di seluruh Kabupaten Kota di Provinsi Sulawesi Utara.namun yang terbesar di daerah Kabupaten Kepulauan Sitaro,Kabupaten Kepulauan Sangihe, Kabupaten Kepulauan Talaud, Kabupaten Minut dan Kabupaten Minahasa. 
Tabel 4.Luas Areal Sentra Pertanaman Pala Di Sulawesi Utara

\begin{tabular}{|c|l|c|c|}
\hline \multicolumn{3}{|c|}{ Data Luas Lahan dan Produksi } \\
\hline NO & Kab / Kota & Luas Areal (Ha) & Produksi (Kg/Thn) \\
\hline 1 & Minahasa & 366.50 & 57.91 \\
\hline 2 & Minsel & 468.02 & 55.29 \\
\hline 3 & Minut & $1,831.04$ & 196.26 \\
\hline 4 & Mitra & 438.93 & 55.01 \\
\hline 5 & Bolmong & 405.70 & 31.12 \\
\hline 6 & Bolmut & 81.01 & 7.49 \\
\hline 7 & Bolsel & 74.47 & 9.80 \\
\hline 8 & Boltim & 129.76 & 14.10 \\
\hline 9 & Sangihe & $4,156.90$ & $2,413.40$ \\
\hline 10 & Talaud & $5,316.80$ & $3,955.85$ \\
\hline 11 & Sitaro & $4,471.76$ & $3,337.25$ \\
\hline 12 & Manado & - & - \\
\hline 13 & Bitung & 645.00 & 62.47 \\
\hline 14 & Tomohon & 15.53 & - \\
\hline 15 & Kotamobagu & 58.85 & 7.23 \\
\hline & JUMLAH & $18,460.27$ & $10,203.18$ \\
\hline Sumber : Dinas Perkebunan Sulut, & 2016 \\
\hline & & & \\
\hline
\end{tabular}

Dinas Perkebunan Prov. Sulut, 2015

\section{Identifikasi Produk Turunan Pala}

Pala (Myristica fragrans Houtt) ,merupakan komoditas perkebunan yang memiliki pasar internasional. Bentuk komoditas pala yang diekspor oleh Indonesia adalah dalam bentuk biji pala, fuli, dan pala glondongan. Ekspor Pala Sulut ini tersebar di Negara Asia, Eropa, Amerika hingga Afrika. 75\% dari kebutuhan pala dunia, dipasok dariProvinsi Sulawesi Utara dimana ekspor pala setiap bulan berkisar 1.000 hingga 2.000 tondari kebutuhan dunia yang berkisar 20.000 ton setiap tahun

Tanaman Pala sebagai bahan pembentuk cita rasa untuk bahan makanan dan minuman berbahan baku Pala. Sulawesi Utara sebagai provinsi penghasil pala utama di Indonesia, dengan sentra produksi utama di Kabupaten Kepulauan Siau Tagulandang Biaro (SITARO), Kabupaten Kepulauan Talaud, dan Kabupaten Minahasa Utara.
Daging pala sudah dimanfaatkan tetapi pasarnya masih terbatas, dan masih dalam pasar domestik dan lokal. Biji pala dapat menghasilkan minyak atsiri sebesar 2 hingga 16 persen, minyak pala mencapai 88 persen dan minyak kental (fixed oil) sebesar 25 hingga 40 persen.

Minyak atsiri pala diperoleh dari biji pala.Pemanfaatan daging pala teridentifikasi masih kurang dan kebanyakan menjadi limbah di perkebunan.Potensi ini yang harus dikembangkan untuk meningkatkan nilai tambah turunan pala khususnya potensi sebagai bahan pangan unggulan.

Berdasarkan hasil penelitian terhadap 45 pengolah produk pangan berbahan baku Pala, teridentifikasi produk olahan yang diproduksi di Kabupaten Kepulauan Siau Tagulandang Biaro yang berbahan baku Daging Pala adalah Dodol Pala, Selai Pala, Permen Pala, Manisan Pala, Sirup Pala, Juice Pala dan Anggur Pala, seperti disajikan pada Gambar 1.

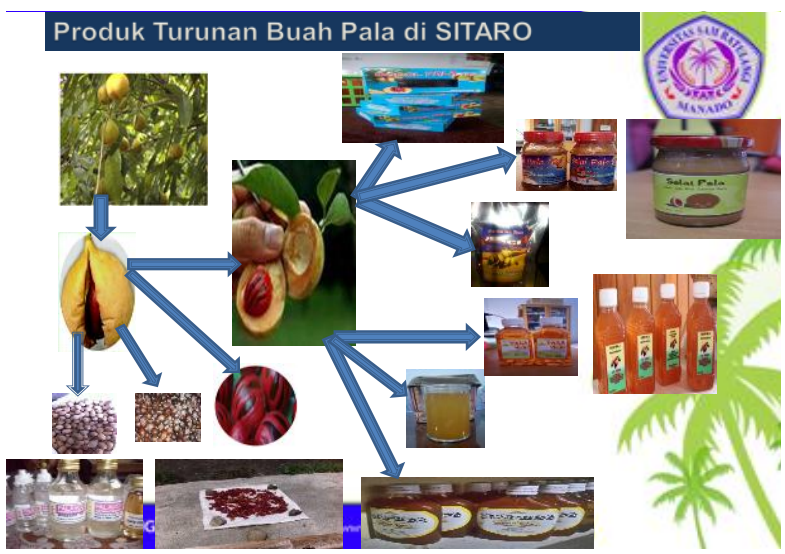

Gambar 1. Produk Turunan Daging Pala di Kab. Kepl. SITARO

Berdasarkan hasil penelitian terhadap 45 produsen pengolah produk turunan daging buah pala maka dari indikator Jenis Produk Turunan yang diolah, Harga Produk Turunan Pala, Ketersediaan Bahan Baku, Jaminan Pasar, Ketersediaan Tenaga Kerja dan pengetahuan tentang pengolahan produk maka terpilih tiga jenis produk turunan daging pala yang unggul berdasarkan indikator yang telah ditetapkan dalam penelitian ini. Tiga produk turunan pala yang unggul berdasarkan indikator, terpilih Produk Dodol Pala, Selai Pala dan Juice Pala.Tiga Produk ini merupakan Produk Pangan yang terdiri dari dua produk makanan yakni Dodol dan Selai serta Sirup Pala sebagai produk minuman. 


\section{Produk Dodol Pala}

Produk Dodol Pala merupakan salah satu produk pangan dengan menggunakan bahan baku daging buah Pala. Pengolahan daging pala yang dicampur dengan tepung ketan menjadikan dodol pala sebagai produk pangan unggulan dengan cita rasa khas dan memiliki permintaan yang cukup tinggi di pasar di daerah.

Bahan yang dibutuhkan untuk mengolah Dodol Pala adalah Tepung Ketan, Gula merah dan Gula Pasir, buah kelapa untuk santan kental dan santan cair, dan Daging Pala. Cara Produksi Dodol Pala adalah pertama adalah memasak tepung ketan yang dicairkan dengan santan cair dan campuri gula merah yang diiris-iris sampai halus, sehingga kental dan berminyak. Daging pala diblender halus dan dicampurkan dalam adonan awal, aduk hingga merata. Selanjutnya bahan dimasak hingga mendidih dan diangkat,dengan meletakkan di atas wadah yang dilapisi kertas minyak, dan supaya tidak lengket, diolesi minyak. Didinginkan, setelah dingin digulung bulat-bulat panjang dan dibungkus dengan kertas minyak atau plastik.

Harga Produk Dodol Salak yang telah dikemas Rp. 15.000 per kemasan seperti pada Gambar 2.Dengan ukuran 130 gram setiap kemasan.

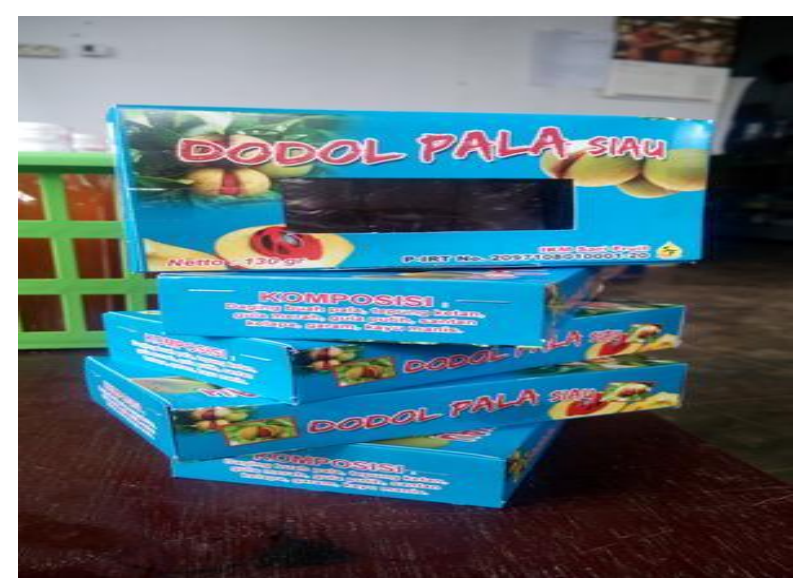

Gambar 2. Dodol Salak yang telah dikemas

Ketersediaan Bahan Baku dalam pengolahan produk selalu tersedia, baik sebagai bahan baku utama maupun bahan penolong. Ketersediaan Bahan Baku menjamin kontinuitas proses produksi.

Jaminan Pasar terhadap produk Dodol Pala terus meningkat seiring dengan berkembangnya berbagai strategi pemasaran.Pemasaran yang dilakukan oleh pengusaha di Kabupaten Kepulauan Sitaro, selain menjual di lokasi produksi, juga dititipkan di toko atau minimarket di daerah Kabupaten Kepulauan SITARO.Produk juga dikirimkan ke toko souvenir di Kota Manado dan di Supermarket di Kota Manado.Strategi Pemasaran Produk lainnya yang dilakukan adalah dengan system online.Pemasaran system online salah satu dilakukan oleh IKM Sari Fruit yang merupakan salah satu rumah produksi yang memproduksi secara kontinue produk Dodol Pala di Kabupaten Kepulauan SITARO.

Ketersediaan Tenaga Kerja dalam produksi sebagian besar menggunakan tenaga kerja dalam keluarga. Biasanya tenaga kerja yang dibayar adalah tenaga kerja yang menyiapkan bahan baku daging pala yang berasal dari perkebunan dan dibawa ke rumah produksi. Tenaga kerja yang dilakukan dalam proses produksi biasanya juga menggunakan tenaga kerja lepas yakni bila pesanan lebih besar dari produksi biasanya, barulah digunakan tenaga kerja tambahan dari luar keluarga.

Pengetahuan tentang pengolahan produk Dodol Pala diperoleh dari workshop pengolahan dodol yang difasilitasi oleh Bank Indonesia Manado, dan ada juga yang merupakan binaan dari Dinas Perindustrian dan Perdagangan Provinsi Sulawesi Utara dan Kabupaten Kepulauan SITARO.

\section{Produk Selai Pala}

Selai Pala merupakan produk pangan yang diolah dari daging buah pala.Memiliki rasa yang khas sesuai dengan aroma pala yang harum. Buah pala yang masak petik merupakan bahan baku terbaik untuk membuat selai karena aromanya sangat khas. Selai pala biasanya digunakan sebagai isi roti dan kue kering. Bahan untuk membuat selai adalah daging buah pala yang masak petik, bahan tambahan adalah gula pasir, dapat digunakan bahan pengawet yakni naatrium benzoate atau kemasan berikut isinya dipasteurisasi supaya produk dapat bertahan lebih lama.

Cara membuat selai pala dengan menggunakan bahan baku utama daging pala 500 biji, dan gula pasir $1 \mathrm{~kg}$. Cara Membuatnya adalah dengan mengupas kulit daging buah pala, kemudian pala yang telah bersih dipotongpotong dan diparut. Hasil pala yang telah diparut dimasak dengan air dan gula hingga 
mendidih, kemudian dinginkan. Setelah itu air rebusan disisihkan.Air rebusan ini dapat simpan dan digunakan sebagai campuran dengan gula pada waktu merebus daging pala yang sudah dihaluskan.Merebus Pala dilakukan secara berulang-ulang hingga 3 kali, untuk menghilangkan rasa asam pala.Setelah itu Pala diblender dagingnya sampai halus. Setelah itu, dimasak dengan air, dan dicampur dengan gula.Untuk mendapatkan bau yang harum, diberi bubuk kayu manis.Untuk membuat produk menjadi lebih awet, produk selai dapat dipanaskan atau dihangatkan, dan taburi lagi gula pasir hingga warna menjadi warna lebih tua, hitam atau merah. Ini merupakan cara mengawetkan tanpa bahan pengawet kimia yang dapat menjadikan selai pala tahan selama berbulan-bulan. Gambar Selai Pala disajikan pada Gambar 3.

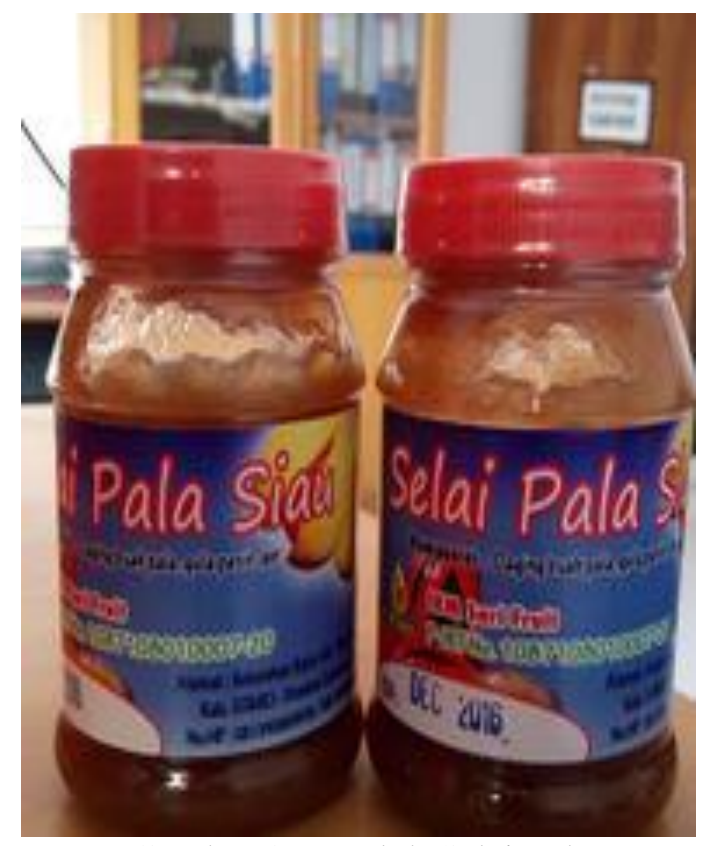

Gambar 3. Produk Selai Pala

Gambar 3 menunjukkan produk selai pala yang telah siap di pasarkan. Produk di kemas dalam botol plastik dan diberi label serta tanggal kadaluarsa. Harga Produk Selai Pala Rp. 20.000.- per botol.

Ketersediaan Bahan Baku dalam pengolahan produk selai selalu tersedia, baik sebagai bahan baku utama yakni daging buah pala yang banyak tersedia maupun bahan penolong yakni gula putih. Ketersediaan Bahan Baku akan menjamin kontinuitas proses produksi.Harga Gula putih yang terus meningkat merupakan salah satu penyebab harga selai pala terus meningkat.

Jaminan Pasar terhadap produk Selai Pala diproyeksikan baik.Permintaan terhadap Selai Pala terus meningkat.Kemasan dalam botol plastic, saat ini mulai divariasikan dengan kemasan botol kaca. Pemasaran yang dilakukan oleh pengusaha di Kabupaten Kepulauan Sitaro, dijual di lokasi produksi, dititipkan di toko atau minimarket, dikirimkan ke toko souvenir dan Supermarket di Kota Manado. Strategi Pemasaran Produk lainnya yang dilakukan adalah dengan system online.Pemasaran system online salah satu dilakukan oleh IKM Sari Fruit yang merupakan salah satu rumah produksi yang memproduksi secara kontinue produk Selai Pala di Kabupaten Kepulauan SITARO.

Ketersediaan Tenaga Kerja dalam produksi sebagian besar menggunakan tenaga kerja dalam keluarga. Biasanya tenaga kerja yang dibayar adalah tenaga kerja yang menyiapkan bahan baku daging pala yang berasal dari perkebunan dan dibawa ke rumah produksi. Tenaga kerja yang dilakukan dalam proses produksi biasanya juga menggunakan tenaga kerja lepas yakni bila pesanan lebih besar dari produksi biasanya, barulah digunakan tenaga kerja tambahan dari luar keluarga.

Pengetahuan tentang pengolahan produk Selai Pala diperoleh dari workshop pengolahan Selai Pala oleh Bank Indonesia Manado, dan dari Dinas Perindustrian dan Perdagangan Provinsi Sulawesi Utara dan Kabupaten Kepulauan SITARO.

\section{Produk Sirup Pala}

Buah pala yang dijadikan sirup pala atau sejenis minuman yang menyehatkan, memiliki berbagai manfaat bila dikonsumsi. Beberapa sumber menyatakan bahwa sirup pala bermanfaat untuk :

1. Mengobati masuk angina

2. Menghilangkan rasa sulit tidur( insomnia)

3. Memperlancarpencernaan

4. Meningkatkan selera makan

5. Memperlancar buang angina

6. rasa mual mau muntah

7. Meredakan nyeri haid dan Mengobati jerawat dan rematik.

Sirup pala bisa dicampur dengan berbagai jus, air soda, dan es batu. 
Bahan untuk membuat Sirup Palaadalahair rebusan buah pala yang dibuang pada pembuatan selai pala.Cara membuat adalah pertamaair rebusan dimasak dengan gula pasir dengan perbandingan 1 liter air dengan 1 $\mathrm{kg}$ gula.Masak hingga mendidih dan mengental.Bisaditambahkan pewarna makanan/minuman untuk tampilan, namun lebih disarankan tidak menggunakan zat pewarna tersebut, biarkan warna alaminya.Setelah mendidih dan mengental, didinginkan dan siap dikemas dalambotol.Gambar produk Sirup Pala disajikan Pada Gambar 4.

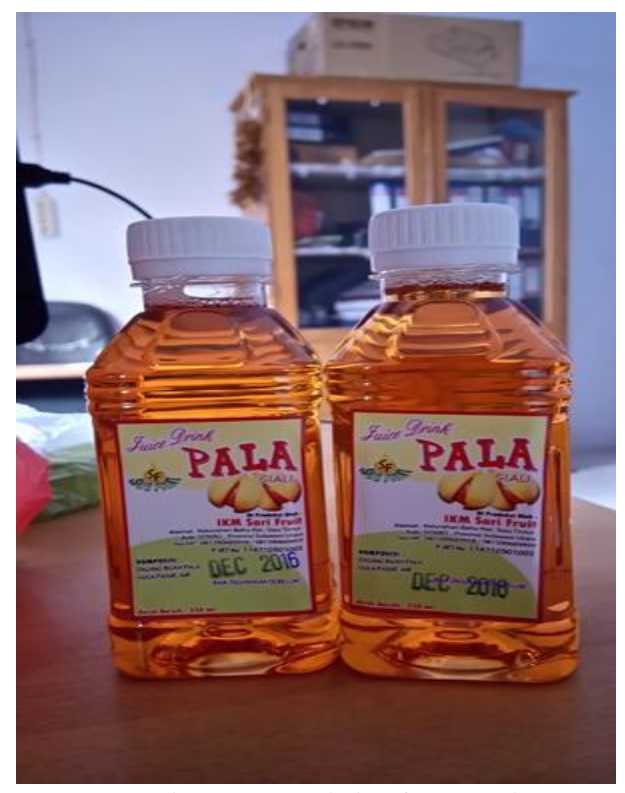

Gambar 4. Produk Sirup Pala

Seperti halnya produk Dodol dan Selai Pala, dari sisi bahan baku, ketersediaan pasar, tenaga kerja dan cara pengolahan, memiliki karakteristik yang sama. Kelebihan Produk Sirup Pala, adalah dari sisi bahan baku yang merupakan produk ikutan dari pengolahan selai, sehingga pengolahan ini adalah zero waste atau tak ada bagian yang terbuang, atau terjadi efisiensi produksi.

\section{Pola Pembiayaan}

Pengembangan usaha kecil dan Rumah Tangga, terdapat beberapa kendala dari sisi usaha kecil terhadap akses permodalan, termasuk Perbankan. Kendala kurangnya akses terhadap pembiayaan dari bank karena ketidakmampuan usaha kecil untuk memenuhi persyaratan dari bank.Tidak ada jaminan dan perizinan, keterbatasan dalam aspek pemasaran, teknis produksi dan manajemen.

Dalam rangka meningkatkan akses bank terhadap usaha kecil, Kabupaten Kepulauan Siau Tagulandang Biaro menjadi salah satu sentra usaha binaan dari Bank Indonesia. Terkait dengan pengembangan produksi pangan berbahan baku daging pala, pelaku industri pengolahan makanan dan minuman berbahan baku daging pala sudah pernah mendapatkan bantuan teknis dari bank melalui akademisi yang terkait dengan kompetensinya, untuk memberikan pelatihan, penelitian maupun konsultansi kepada Usaha Kecil dan Rumahtangga Pengolah Produk Pangan Berbahan Baku Daging Buah Pala.

Dalam memenuhi kebutuhan modal usaha pengolahan Dodol Pala, Selai Pala dan Minuman Sirup Pala, berdasarkan hasil penelitian teridentifikasi produsen industri yang sebagian besar dalam skala rumah tangga atau industri kecil, menggunakan modal sendiri dan ada juga yang telah mendapatkan fasilitas dari Perbankan, namun dalam bentuk peralatan dan pembinaan sumberdaya manusia serta modal kerja. Selain itu, terdapat pula industri rumahtangga yang mendapatkan modal usaha dari pedagang dengan jaminan membeli hasil produk untuk dipasarkan dalam jaringan pemasarannya.

Berdasarkan Data dari 45 industri kecil pengolahan berbahan baku daging pala yang menjadi sampel secara Purposive di Kabupaten Kepulauan Sitaro adaah 30 pengolah. Hasil penelitian menunjukkan bahwa teridentifikasi 60 persen pengusaha mendapatkan bantuan Modal Usaha dari Pemerintah.Terdapat 10 persen pengusaha mendapat bantuan dari Bank, tapi melalui program dan kegiatan dari Bank Indonesia. 10 persen lainnya meminjam dari sesama pengusaha 20 persen lainnya menggunakan modal usaha pribadi.

Pola pembiayaan yang teridentifikasi di Kabupaten Kepulaua Siau Tagulandang Biaro untuk pengusaha produk pangan dari turunan pala dapat dijelaskan sebagai berikut:

(1) Pola Pembiayaan dari Pemerintah

(2) Pola Pembiayaan dari Perbankan melalui Bank Indonesia

(3) Pola Pembiayaan Pinjaman sesama

Pengusaha yang memiliki modal

(4) Pola Pembiayaan Sendiri 
Empat jenis Pola Pembiayaan ini merupakan pola umum di UMKM Pangan berbahan baku Pala di Kabupaten Kepulauan SITARO.Pola pembiayaan Produksi menggunakan Modal Pribadi atau dari Pemerintah merupakan salah satu Pola Pembiayaan yang terbanyak diperoleh dari industri kecil.

\section{Pola Pembiayaan dari Pemerintah} pemerintah

Pola Pembiayaan ini merupakan program

2. Pola Pembiayaan dari Perbankan melalui Bank Indonesia

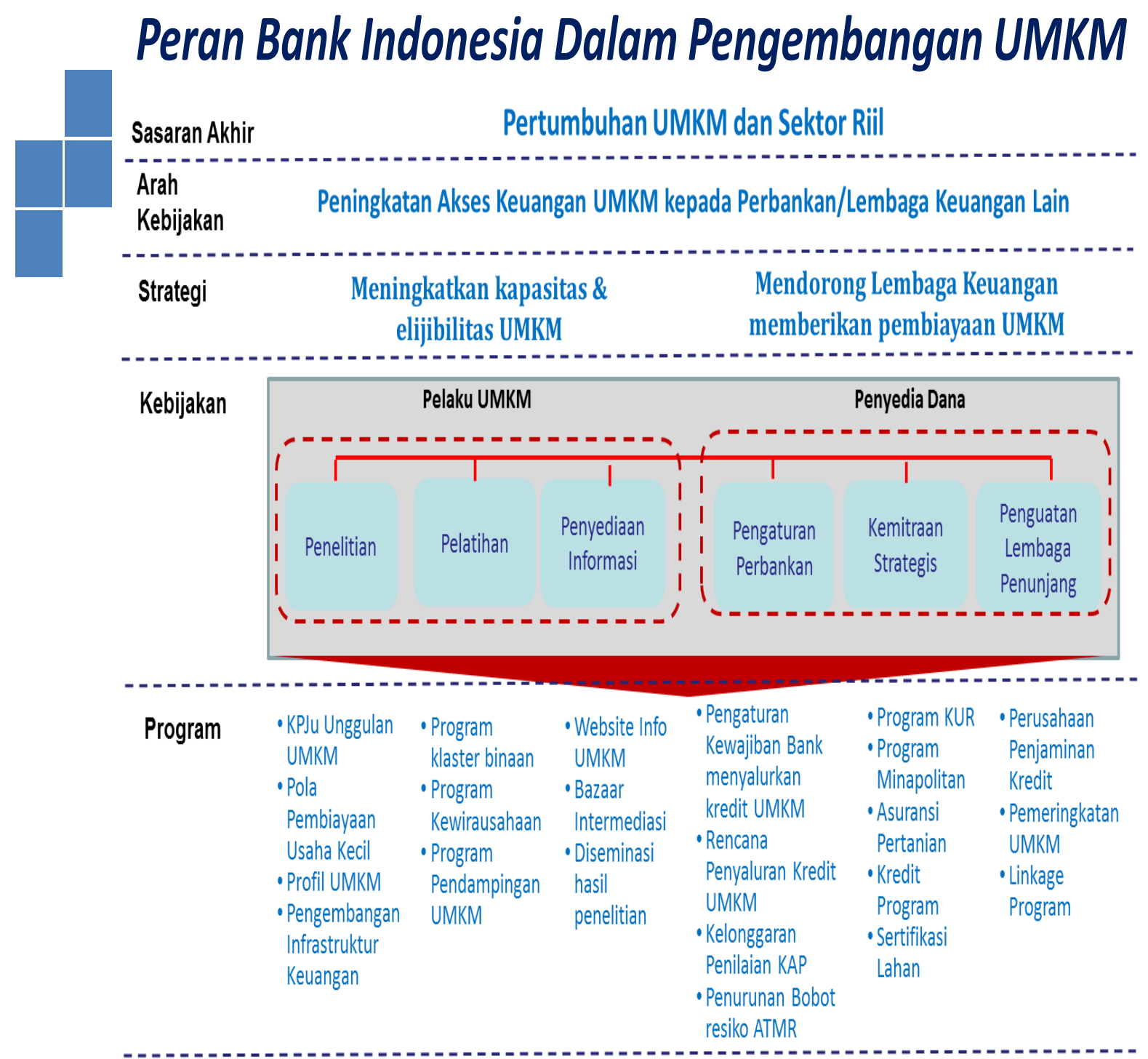

mendukungperkembangan usaha di daerah.Terdapat beberapa Pola Pembiayaan yang difasilitsi Pemerintah, antara lain Pemerintah Provinsi Sulawesi Utara melalui Dinas Koperasi dan UMKM memberikan pinjaman dana penguatan modal Lembaga Keuangan Mikro (LKM) atau Usaha Kecil Mikro (UKM). Pinjaman ini untuk produk UKM yang tidak terbatas untuk produk pangan berbahan baku pala. Sumber dana pinjaman ini dari Anggaran Pendapatan dan Belanja Daerah (APBD) Propinsi.
dalam
rangka




\section{Pola Pembiayaan Pinjaman sesama Pengusaha yang memiliki modal}

Pola Pembiayaan ini dilakukan oleh pengusaha yang melakukan produksi tapi kekurangan modal dan tidak memiliki akses lainnya .Pedagang yang dimaksud adalah yang memiliki toko atau berjualan dipasar, yang memberikan pinjaman dengan bunga 5 persen.Produk yang dihasilkan dibeli oleh mereka sehingga pinjaman langsung diperhitungkan saat membawa produk.

\section{Pola Pembiayaan Sendiri}

Pola Pembiayaan ini merupakan pola umum di UMKM Pangan berbahan baku Pala di Kabupaten Kepulauan SITARO. Pembiayaan Produksi menggunakan Modal Pribadi. Peralatan yang digunakan masih sederhana dengan operasional pengolahan produk dengan memanfaatkan dana sendiri. Pelaku usaha ini hanya mampu memproduksi sesuai kapasitas pengolahan yang tersedia dan menggunakan tenaga kerja dalam keluarga.

\section{KESIMPULAN DAN SARAN}

\section{Kesimpulan}

1. Jenis Produk Unggulan berbahan baku Daging Pala di Sitaro Sulawesi Utara : Dodol Pala, Selai Pala dan Sirup Pala

2. Terdapat 4 Pola Pembiayaan Pengolahan Pala sebagai Komoditi Pangan Unggulan yakni : Pola Pembiayaan dari Pemerintah,Pola Pembiayaan dari Perbankan melalui Bank Indonesia, Pola Pembiayaan Pinjaman sesama Pengusaha yang memiliki modal dan Pola Pembiayaan Sendiri.

\section{Saran}

1. Produk Pangan unggulan yang teridentifikasi harus terus ditingkatkan kualitas dan kuantitas produk sehingga bukan hanya menjadi sumber pangan di daerah tapi juga memberikan dampak peningkatan pendapatan bagi rumahtangga pengolah produk turunan pala.
2. Ketergantungan terhadap bantuan pemerintah harus dikurangi dan pola pembiayaan dapat dikombinasikan antar pola yang telah terbentuk.

3. Pola Pembiayaan dengan Skim Kredit belum terpola sehingga menjadi salah satu alternative pembiayaan dalam pengembangan usaha pengolahan produk pala sebagai komoditi pangan unggulan di daerah.

\section{DAFTAR PUSTAKA}

Anonimous. 2015. Neraca Bahan Makanan. Angka Tetap 2013. Badan Ketahanan Pangan. Provinsi Sulawesi Utara. Manado

2014.Peta Situasi Pangan dan Gizi. Badan Ketahanan Pangan. Provinsi Sulawesi Utara. Manado

2013.Grand Design Perkebunan Provinsi Sulawesi Utara.Dinas Perkebunan Provinsi Sulawesi Utara. Manado

2013.Kajian Distribusi Bahan Pokok Masyarakat di Sulawesi Utara. Laporan Akhir Penelitian. Badan Ketahanan Pangan Provinsi Sulawesi Utara. Manado.

Fred D.R. 2006. Manajemen Strategis. Edisi Kesepuluh. Salemba Empat. Jakarta

Kotler, Philip., 2001. Manajemen Pemasaran di Indonesia. Analisis, Perencanaan, Implementasi dan Pengendalian. Salemba Empat. Jakarta.

Mursid, M. 2003. Manajemen Pemasaran. Bumi Angkasa-Ekonomi. Universitas Indonesia. Jakarta.hain Management

Pakasi C.B.D, dkk 2012. Kajian Pemasaran pala di Provinsi Sulawesi Utara. Laporan Akhir Penelitian. Badan Perencanaan Pembangunan Provinsi Sulawesi Utara. Manado 
Tuerah N, C.B.D. Pakasi, H. Anapu, dan M.Kamagi. $2012 . \quad$ Kajian Pengembangan Pala di Sulawesi Utara. Laporan Akhir Penelitian. Kementerian Riset dan Teknologi RI kerjasama dengan Bappeda Prov. Sulut. Manado
Soekartawi. 2002. Prinsip Dasar Manajemen Pemasaran Hasil-Hasil Pertanian. Teori dan Implikasinya.Raja Grafindo Persada. Jakarta.

Solihin A. 2002. Pembangunan Ekonomi Wilayah Perbatasan. Penerbit PT. Alumni Bandung.Edisi kedua.Cetakan kesatu. Bandung 